ISSN 2080-1653

DOI 10.24917/20801653.353.12

\author{
VITALII IVANUNIK \\ Yuriy Fedkovych Chernivtsi National University, Ukraine \\ HALYNA KRUL \\ Yuriy Fedkovych Chernivtsi National University, Ukraine \\ STEPAN BRYK \\ Yuriy Fedkovych Chernivtsi National University, Ukraine
}

\title{
Assessment of the impact and interrelation of UNESCO World Heritage on the tourism attractiveness of the country
}

\begin{abstract}
This work aims to investigate the impact of popular UNESCO World Heritage objects on the country's tourist arrivals as a factor of attractiveness, to estimate the strong correlation between these phenomena, and to mathematically validate the assumption that the number of such sites has a direct impact on the country's tourism competitiveness. We used data from the UNWTO's open sources, UNESCO, the World Economic Forum expert reports on the competitiveness of travels and tourism of the world's countries for 2017. The analysis is based on three rankings of countries in terms of World Heritage assets, international touristic arrivals and the country's tourism and travel competitiveness index, and correlation analysis between these values. Also, to determine the influence and interdependencies between the studied concepts, the method of paired correlation analysis was chosen as a convenient way to demonstrate the influence of one variable on another. Determination of the correlation coefficient allowed to speak about the complexity of the relationship and the linearity of these phenomena. In particular, the increase in the number of UNESCO World Heritage sites leads to an increase in tourist arrivals and makes the country attractive for tourism development. As a result, we have obtained estimates of the unidirectional impact of the number of World Heritage sites on the territory of a particular country on the volume of international tourist arrivals. However, not always the overall attractiveness and competitiveness of the country in the field of tourism is linked to the World Heritage, and our study only confirms the thesis that among the many ways to increase the attractiveness of the country, an increase in World Heritage sites leads to an increase in tourist traffic. In current trends, choosing public policy to enhance and preserve UNESCO sites one obviously can expect the growth of tourist flows to the countries.
\end{abstract}

Keywords: international touristic arrivals, tourism attractiveness, Travel and Tourism Competitiveness Index, UNESCO World Heritage

Received: 3 March 2021

Accepted: 8 May 2021

\section{Suggested citation:}

Ivanunik, V., Krul, H., Bryk, S. (2021). Assessment of the impact and interrelation of UNESCO World Heritage on the tourism attractiveness of the country. Prace Komisji Geografii Przemysłu Polskiego Towarzystwa Geograficznego [Studies of the Industrial Geography Commission of the Polish Geographical Society], 35(3), 186-204. doi: https://doi.org/10.24917/20801653.353.12 


\section{INTRODUCTION}

Tourism industry is an important component of the economy of many countries, which is increasing its global significance. Tourism development affects various sectors of the economy, especially in construction, transport, communications, trade, which are the most promising areas of structural reorientation of the economy in the post-industrial era and the distribution of employment in it. An important prerequisite for the effective development of tourism industry on a given territory is an increase in the number of foreign tourists and the inclusion of local residents in the domestic tourist flow. A steadily increasing tourist flow supplies the economy with income, which leads to an increase in the socio-economic development of the territory and the improvement of social standards.

Competition between countries in the global tourism market for the distribution of tourism revenues forces specialised state organisations and private companies to increase the quality and quantity indicators of tourism appeal of the territory. One of the criteria for confirming the generally accepted global trend in choosing state policy on the attractiveness of the country as a whole is the concept aimed at developing tourism in the country through the popularisation and status of the natural and cultural superstructure. The accumulation of UNESCO World Heritage sites on its territory as status, popular and unique attractions which act as a magnet for the flow of tourists to the country as a whole is regarded as a success.

\section{ANALYSIS OF RECENT STUDIES AND PUBLICATIONS}

The study of any phenomenon or process requires the primary clarification of its essence, the identification of methods that better reveal this essence, and the interrelation with other processes and phenomena. As noted above, this article examines the impact of UNESCO World Heritage Sites on the attractiveness of a country through the close relationship with tourist arrivals, and as a result, the relevant calculations confirm the assumption that the number of such sites influence the tourist visitation of countries. So, the task is to clarify the essence of the basic concepts to which this study is devoted, namely, "tourist potential", "tourist attractiveness", "tourist competitiveness", and others.

Today there are many scientific approaches and developed methodologies for assessing the tourism potential and attractiveness of the territory. The two indicators are affined, although some scientists consider this connection to be spontaneous and unprecedented. Let us first consider the essence of the concept of "tourism potential of the region". In the second half of the 20th century, the study of the tourist potential of a particular territory was a subject of research of many economists, who considered it through the prism of economic concepts. A detailed review of various approaches to the interpretation of the term "tourist potential" is given in the article by Iaţu and Bulai (2011). For example, Snak (1976, cited in Iaţu, Bulai, 2011: 165), believes that "the basic tourist supply is the main prerequisite in the planning and functioning of some forms of tourism". Muntele and Iaţu (2006, Iaţu, Bulai, 2011) interpret tourist potential as "the totality of natural, social, cultural and historical resources that support the tourist offer of a certain territory". 
In the 1990s, the problem of defining and calculating tourism potential flooded the geographical and economic literature without specifying its meaning and objectives. Today, there are two main trends in defining the concept of "tourism potential": the first one is related to the attribution of non-material factors to this concept. This is the opinion of Glăvan (2005), who perceives it as "the sum of opportunities provided by the natural and social environment at the disposal of tourist activity", whereas Hall, Page (2004, 2014) see it as "basic conditions of development."

However, the "materialistic approach" considers the tourism potential as "the sum of natural and human resources" (Iațu, Bulai, 2011; Ielenicz, Comănescu, 2006; Ielenicz, Comănescu, Nedelea, 2010). The LEADER European Supervisory Programme defines tourism potential as the relationship between tourism supply, demand, market trends and competition (2005, 2011; Iațu, Bulai, 2011). According to Goeldner and Ritchie (2003, 2009; Iațu, Bulai, 2011), the tourism proposition can be divided into four components: natural resources, anthropogenic environment, touristic sector activities and cultural resources.

Therefore, tourism potential is a qualitative, non-material measure of certain subjective capacities and conditions, while the tourism proposition may include both existing and possible components that depend on a survey approach or a territorial assessment project. But the tourism proposition does not explain the development of tourism by the range of demand. Therefore, Formica (2000, cited in Iațu, Bulai, 2011: 166) defines the relationship between the demand and the offer as tourism attractiveness which "depends on the balance between the availability of existing tourism attractions and their importance." Unlike potential, which is part of the proposition, tourism appeal requires an approach that is based on the dependence between possible and available elements and tourism demand (Lovingwood, Mitchell, 1989, cited in Iațu, Bulai, 2011: 166), i.e. it is a function of the interplay of proposition and demand. It is the appeal that allows assessing the impact of territorial internal forces (proposition) on external forces (demand) and vice versa.

Current research on the tourist potential of certain territories covers mainly geographical issues (availability of resources, infrastructure, services), but not the analysis of the degree of their correlation or significance, which interferes with the knowledge of the impact of these indicators and elements of the tourism sphere on the regional economy. The shortcoming is the use of indicators of tourist demand in the research, expressed by determining the number of arrivals, the number of overnight stays, the average stay duration, tax and budget revenues, motivation of tourist trips, etc. Also, there is a need to study the tourist potential in terms of tourist appeal. The methods suggested by Smith (1987), and supplemented by Lovingwood and Mitchell (1989), referenced in Iațu and Bulai (2011), lean against a wide range of tourism data (hotel rooms, restaurants, campsites, number of natural features etc.). Using their method of research on the basis of a real analysis of all components, to identify territorial formations (clusters) with similar resource characteristics, allows to reveal the economic importance of tourism in any particular region or country.

Analysing the available publications on regional tourism, we observe a high degree of the use of the term "tourism attractiveness of the region". However, there is a reason to believe that not only is there no common understanding of this concept, but there is no clear definition that meets scientific requirements. Considerable attention to the interpretation of the term "tourist attractiveness" was paid at different times 
by Benckendorff $(2004,2006)$ and Kruczek $(2015)$. According to them, the problem in a unified interpretation of this concept is also complicated by the fact that there are no common approaches or quantitative indicators that allow to assign this or that place in the category of "outstanding" or "attractive". In his monograph, based on previous thorough studies by Benckendorff (2004), Kruczek (2011) systematised approaches to the definition of the concept of "tourist attractiveness" by tourism classics Cohen (who first used the term in 1972), Lundberg (1985), Leiper (1979), Davidson (1996), Middleton (1996, 2003), Lew (1987), etc., comprehensively complemented the interpretation of "tourist attractiveness" and, summarizing them, proposed to consider as tourist-attractive places "all constituent elements of the tourist product (weighty places and events, objects and authentic works of culture), defined as unique and such that are able to attract tourists and make them choose a particular area".

According to McKenzie and Adams (2018), the primary motivation of tourists is often driven by the desire to visit a unique attraction in a particular location. The attractiveness of the latter depends on the quality and status of the site, as some travelers are seduced by a particular attraction, while others prefer thematic travel. Therefore, the presentation of associative attractions as a showcase of a country attracts the tourist to the destination in general. Cmeciu and Druga (2011) agree and confirm the point, they believe that apart from Count Dracula, Ceausescu and Comaneci, monasteries of Moldova and Bukovina (eastern and northern part of Romania) constitute a permanent brand of the country, inseparably linked in the mind of every foreign tourist with Romanian atmosphere.

A different opinion is held by Husbands (1983), whose point is that the problem of evaluation and measurement of tourism attractiveness concerns countries as a whole. He notes that even if the peculiarity of a country allows it to become tourism attractive by resource heritage (as the primary motivation), there are other factors that level the initial potential: the sphere of security, health care, the level of freedom and the like. The phenomenon of tourism is expressed as the formation of a system with a peculiar way of organising a comfortable life.

So, the tourist attractiveness of a region is nothing but the assessment of potential tourists' ability to meet their needs in the region. Tourist attractiveness, as an evaluative category, is characterised by a set of factors, they are interrelated and have varying degrees of importance for the overall assessment.

In their study Korol and Krul (2020) define the attractiveness of the territory of a country through the indicators of area and population, which are divided and correlated with the number of tourist arrivals, leaning against various geographical factors, including the climate. However, in our opinion, this analysis of attractiveness does not meet the emotional component of tourist arrivals.

A group of scientists (Truchet et al., 2016) in their study notes that the level and status of attractiveness of tourist attractions and their spatial characteristics are determinants of tourism development. However, they take into account the impact of tourist attractions on the number of hotel rooms and the number of employees in the tourism sector, which does not fully reflect the direct relationship between the presence of outstanding sites and tourist flows.

Du Cros (2008) notes that UNESCO World Heritage sites are often popular and the main attractions of a particular location, particularly in terms of the economic benefits they bring due to increased attendance and extended stays. However, it is difficult to 
achieve the result without quality management and promotion of these sites. In addition, this phenomenon has the opposite effect, when the excessive number of tourists negatively affects the quality of the attraction, as discussed in the article by Gao, $\mathrm{Su}$, Zang (2020) based on the example of China. A group of researchers (Kaharuddin et al., 2021) concluded that the tourist's motivation to choose a destination is influenced not only by the presence of an outstanding attraction, but also by the quality of service and its level of satisfaction. This thesis was confirmed through a survey on World Heritage Sites in Northern Ireland in Kempiak et al. (2017).

Having studied and analysed the opinions of varios scientists, we formulate the definition of "recreational and tourist attractiveness of the territory" as a complex potential of tourist resources to attract (lure) consumers on the one hand, and attractive economic and natural conditions for investment and development of a particular territory, creating an appropriate comfortable environment for the relevant activities on the other. We believe that the primary attractiveness of the country depends on the cumulative diversity of a certain number of natural and cultural tourist resources. Secondary attractiveness (general) is the quality of tourist infrastructure development on the basis of the primary component and the level of accessibility to it (Ivanunik, Yavkin, 2012).

Thus, in our opinion, modern tourist attractiveness is nothing but the assessment of potential tourists' ability to meet their own needs by visiting the chosen country. Tourist attractiveness, as an evaluative category, is characterised by a set of indicators that are interrelated and have different degrees of subjectivity between them in terms of travel motives.

\section{STUDY OBJECTIVES}

This study aims to demonstrate the impact of World Heritage on the attractiveness of the country through a close relationship with tourist arrivals, to confirm the assumption that the number of World Heritage sites directly affects the tourist attractiveness and popularity of the country and prove it by calculations.

\section{SOURCE MATERIAL AND METHODOLOGICAL BASIS}

The study is based on statistics and methodology of international tourism assessment proposed by the UN World Tourism Organization (UNWTO), as well as using systematised data of UNESCO, characterising the object base of the World Heritage Site. For a basis of research the data of the report of experts of the World economic forum on competitiveness of travel and tourism of the world that is expressed by an index TTCI (Travel \& Tourism Competitiveness Index) are also taken.

Undoubtedly, the concept of "tourism attractiveness" is a multidimensional and complex characteristic of a destination. As today there is no unified interpretation of the term "tourist attractiveness", so there is no unified method for determining the level and degree of attractiveness of a particular territory. The methodology of research in tourism was studied by Scott, Baggio, Cooper (2008), Hair i in. (2010), Baggio, Klobas (2011), Dwyer, Gill, Seetaram (2012) and many other experts in the tourism industry, but we used a system of tourism rating, which is advisable to apply, taking into account the accumulated experience in international practice, which is the subject of our study. 
Proceeding from the goal, we chose and formed three ratings, which indirectly demonstrate the attractiveness of the countries for further primary analysis (see Table 1). Each rating is based on a single indicator, from higher to lower.

The first rating (the main factor) is a selection of countries by the presence of UNESCO World Heritage sites on their territory, which already demonstrates a certain attractiveness. This ranking includes 56 countries that have more than five sites (this is an evaluation criterion). Note that the UAE, which has only one UNESCO World Heritage Site, was visited by almost 16 million tourists in 2017. Almost the same number visited India, which has 38 sites and ranks 6th in the world. So, such a sample is made deliberately in order to get a correct result for further analysis and exclude fluctuations of indicators in the correlation. Note that the array of sample countries accounts for almost $85 \%$ of the world heritage of UNESCO.

The other two country rankings by natural and relative indicators also have a sample that is derived from the list of World Heritage Sites, and are also formed of 56 countries.

Today there are many methodologies and assessments of tourist attractiveness. Obviously, a simple assessment of the attractiveness of the territory by a quantitative indicator is international tourist arrivals, forming our next ranking of countries. This indicator demonstrates the overall attractiveness of the country and the magnitude of the demand for natural wealth and cultural treasures as the basis of tourism resources. The information is gathered and published annually by the United Nations World Tourism Organization (UNWTO).

The third ranking indicator we use reflects tourism attractiveness in relative terms. Experts of the World Economic Forum in Davos together with the International Air Transport Association (IATA), the International Union for Conservation of the Environment (IUCN), the World Travel \& Tourism Council (WTTC) and the UN World Tourism Organization (UNWTO) form The Travel \& Tourism Competitiveness Index (TTCI) which is published every two years and covers over 130 countries, which, according to analysts, account for over $98 \%$ of world GDP. The Travel \& Tourism Competitiveness Index of a country consists of four main groups: environment, politics, infrastructure, natural and cultural resources.

Despite all the unfluence of experts in determining this index, we would like to note a certain disadvantage in its formation. All fourteen indicators that make up the TTCI have the same weight of influence, summing up the final value. Although, in our opinion, the primary basis of a country's attractiveness in tourism is a group of natural and cultural resources, which create the basis, all other factors act as a superstructure. A typical example of the lack of TTCI score is Turkey - a country with a comfortable climate, diverse environment, rich cultural heritage (a total of 18 UNESCO sites), which by 2017 was visited by almost 38 million tourists (8th place in the world rating), but according to the TTCI index it ranks only 30th. Despite this, this index has a global completeness of attractiveness, which allows for a comprehensive analysis.

Ratings, as an array of data, form an incomplete picture of the destination's attractiveness, they show a certain level, relying only on the dominant factor. However, for a more in-depth analysis of the impact of World Heritage on tourism attractiveness, further we use a method of contrast and comparison of individual factors and their influence on each other in correlation analysis. 
To carry out an assessment of the impact of the UNESCO World Heritage on international tourist arrivals we chose the method of pair correlation, because correlation dependence occurs when one of the values depends not only on a given second, but also on some random factors; or, when among the conditions on which both values depend, there are common for them both. This is particularly appropriate in our case. From the data sets created, we will perform a correlation analysis using Microsoft Excel software to determine the Pearson correlation coefficient.

$$
r=\frac{\sum(x-\bar{x})(y-\bar{y})}{\sqrt{\sum(x-\bar{x})^{2} \sum(y-\bar{y})^{2}}}
$$

(1) where (r) - correlation coefficient Pearson, (x) and (y) numerical values of quantities between which a correlation relationship is established, $(\ddot{x}),(\bar{y})$ - their arithmetic averages.

For functional relationships, the index refers to the interval from 1.0 to 1.0 inclusive and reflects the magnitude of the linear relationship between two sets of data. The correlation is considered strong if ( $\mathrm{r}$ ) is greater than 0.75 , indicating the dependence of one factor on another.

\section{RESULTS OF THE STUDY}

Thus, the authors of the study offer to define the UNESCO World Heritage Site as a status unique micro- (inherent in cultural attractions) and macro-space (natural sites), which expresses the basis of motivational and emotional component of the popularity of the country. In our opinion, the primary motivation of the modern tourist is perceived through unique status locations (including UNESCO World Heritage Sites), which contribute to the growth of tourist flows and the emotional appeal of the country.

1. Let us consider the distribution of UNESCO World Heritage Sites in the world, which occurs, at first glance, by assigning the appropriate status to unique sites. However, there is a pattern that the number of such sites in the country depends on various factors: 1) the historical and cultural heritage of the country (the age of the historical period); 2) the natural diversity of landscape formations; 3 ) the area of the country. The last factor is obvious, but not decisive for the number of World Heritage sites on the territory of a particular country.

If we analyse the formed rating of countries by the number of UNESCO World Heritage sites on their territory, more than half of the first 15 countries are the largest in the world by area, such as Russia, Canada, Australia, USA, Brazil, India, Mexico and China (see Table 1). This fact confirms the thesis that the larger the country, the more likely it is to find UNESCO sites. However, Italy and Spain have a combined total of 105 UNESCO World Heritage Sites (almost 10\%), although these countries are small in size, but have a rich historical and cultural heritage and landscape diversity.

The factor of natural diversity today has the least influence on the distribution of UNESCO World Heritage sites. Only in three countries in the structure natural sites prevail over cultural ones, namely in Canada 11 (natural) out of 20 (total), in the USA 13 out of 24, and in Australia 16 out of 20. Also, Russia and China are rich in natural sites with UNESCO World Heritage status (UNESCO World Heritage List). 
Table 1. Rankings of Countries by Number of UNESCO World Heritage Sites, International Tourist Arrivals and Travel and Tourism Competitiveness Index (2017)

\begin{tabular}{|c|c|c|c|c|c|c|c|}
\hline \multirow[t]{2}{*}{ № } & \multirow{2}{*}{ Countries } & \multicolumn{2}{|c|}{$\begin{array}{l}\text { World Heritage } \\
\text { UNESCO }\end{array}$} & \multicolumn{2}{|c|}{$\begin{array}{c}\text { International Tourist } \\
\text { Arrivals } 2017\end{array}$} & \multicolumn{2}{|c|}{$\begin{array}{c}\text { Travel and Tourism } \\
\text { Competitiveness Index } \\
2017\end{array}$} \\
\hline & & $\begin{array}{l}\text { Quantity } \\
\text { (units) }\end{array}$ & $\begin{array}{l}\text { Rating } \\
\text { position }\end{array}$ & $\begin{array}{c}1000 \\
\text { persons }\end{array}$ & $\begin{array}{l}\text { Rating } \\
\text { poisition }\end{array}$ & TTCI & $\begin{array}{c}\text { Rating } \\
\text { poisition }\end{array}$ \\
\hline 1 & Italy and Vatican & 57 & 1 & 58253 & 5 & 4.99 & 8 \\
\hline 2 & China & 55 & 2 & 60740 & 4 & 4.72 & 13 \\
\hline 3 & Spain & 48 & 3 & 81869 & 2 & 5.43 & 1 \\
\hline 4 & Germany & 46 & 4 & 37452 & 9 & 5.28 & 3 \\
\hline 5 & France & 45 & 5 & 86918 & 1 & 5.32 & 2 \\
\hline 6 & India & 38 & 6 & 15543 & 20 & 4.18 & 26 \\
\hline 7 & Mexico & 35 & 7 & 39291 & 6 & 4.54 & $18-19$ \\
\hline 8 & $\begin{array}{l}\text { United Kingdom of } \\
\text { Great Britain and } \\
\text { Northern Ireland }\end{array}$ & 32 & 8 & 37651 & 7 & 5.20 & 5 \\
\hline 9 & Russian Federation & 29 & 9 & 24390 & 13 & 4.15 & 28 \\
\hline 10 & USA & 24 & $10-11$ & 76941 & 3 & 5.12 & 6 \\
\hline 11 & Iran & 24 & $10-11$ & 4867 & 42 & 3.43 & 50 \\
\hline 12 & Japan & 23 & 12 & 28691 & 11 & 5.25 & 4 \\
\hline 13 & Brazil & 22 & 13 & 6589 & 38 & 4.49 & 21 \\
\hline 14 & Canada & 20 & $14-15$ & 20883 & 15 & 4.97 & 9 \\
\hline 15 & Australia & 20 & $14-15$ & 8815 & 31 & 5.10 & 7 \\
\hline 16 & Greece & 18 & $16-17$ & 27194 & 12 & 4.51 & 20 \\
\hline 17 & Turkey & 18 & $16-17$ & 37601 & 8 & 4.14 & $29-30$ \\
\hline 18 & Portugal & 17 & 18 & 21200 & 14 & 4.74 & 12 \\
\hline 19 & Poland & 16 & 19 & 18400 & 16 & 4.11 & 31 \\
\hline 20 & Sweden & 15 & 20 & 7054 & 34 & 4.55 & 17 \\
\hline 21 & Czechia & 14 & $21-22$ & 13665 & 22 & 4.22 & 25 \\
\hline 22 & Republic of Korea & 14 & $21-22$ & 13336 & 23 & 4.57 & 16 \\
\hline 23 & Belgium & 13 & 23 & 8358 & 32 & 4.54 & $18-19$ \\
\hline 24 & Switzerland & 12 & $24-25$ & 11133 & 28 & 4.94 & 10 \\
\hline 25 & Peru & 12 & $24-25$ & 4032 & 44 & 4.04 & 35 \\
\hline 26 & Argentina & 11 & 26 & 6710 & 36 & 4.05 & 34 \\
\hline 27 & Austria & 10 & $27-32$ & 29460 & 10 & 4.86 & 11 \\
\hline 28 & Bulgaria & 10 & $27-32$ & 8883 & 30 & 4.14 & $29-30$ \\
\hline 29 & Croatia & 10 & $27-32$ & 15593 & 19 & 4.42 & 23 \\
\hline 30 & Denmark & 10 & $27-32$ & 11743 & 26 & 4.43 & 22 \\
\hline 31 & Netherlands & 10 & $27-32$ & 17924 & 17 & 4.64 & $14-15$ \\
\hline 32 & South Africa & 10 & $27-32$ & 10285 & 29 & 4.01 & 36 \\
\hline 33 & Ethiopia & 9 & $33-38$ & 933 & 55 & 3.10 & 54 \\
\hline 34 & Morocco & 9 & $33-38$ & 11349 & 27 & 3.81 & $40-41$ \\
\hline 35 & Colombia & 9 & $33-38$ & 3631 & 45 & 3.83 & 39 \\
\hline 36 & Cuba & 9 & $33-38$ & 4594 & 43 & 3.30 & 52 \\
\hline 37 & Indonesia & 9 & $33-38$ & 12948 & 24 & 4.16 & 27 \\
\hline 38 & Israel & 9 & $33-38$ & 3613 & 46 & 3.84 & 38 \\
\hline 39 & Hungary & 8 & $39-44$ & 15775 & 18 & 4.06 & $32-33$ \\
\hline
\end{tabular}




\begin{tabular}{|r|l|r|r|r|r|r|r|}
\hline 40 & Norway & 8 & $39-44$ & 6252 & 40 & 4.64 & $14-15$ \\
\hline 41 & Romania & 8 & $39-44$ & 2760 & 48 & 3.78 & $42-43$ \\
\hline 42 & Tunisia & 8 & $39-44$ & 7052 & 35 & 3.50 & $47-48$ \\
\hline 43 & Sri Lanka & 8 & $39-44$ & 2116 & 50 & 3.81 & $40-41$ \\
\hline 44 & Viet Nam & 8 & $39-44$ & 12922 & 25 & 3.78 & $42-43$ \\
\hline 45 & Finland & 7 & $45-53$ & 3180 & 47 & 4.40 & 24 \\
\hline 46 & Slovakia & 7 & $45-53$ & 5415 & 41 & 3.90 & 37 \\
\hline 47 & Ukraine & 7 & $45-53$ & 14421 & 21 & 3.50 & $47-48$ \\
\hline 48 & Algeria & 7 & $45-53$ & 2451 & 49 & 3.07 & 55 \\
\hline 49 & Egypt & 7 & $45-53$ & 8292 & 33 & 3.64 & 44 \\
\hline 50 & Kenya & 7 & $45-53$ & 1390 & 51 & 3.59 & 46 \\
\hline 51 & Senegal & 7 & $45-53$ & 1365 & 52 & 3.14 & 53 \\
\hline 52 & Tanzania & 7 & $45-53$ & 1275 & 53 & 3.45 & 49 \\
\hline 53 & Bolivia & 7 & $45-53$ & 1134 & 54 & 3.34 & 51 \\
\hline 54 & Chile & 6 & $54-56$ & 6450 & 39 & 4.06 & $32-33$ \\
\hline 55 & Pakistan & 6 & $54-56$ & 6621 & 37 & 3.60 & 56 \\
\hline 56 & Philippines & 6 & 907 & 56 & 2.89 & 45 \\
\hline
\end{tabular}

Source: compiled by the authors based on data from the UNESCO World Heritage List, UNWTO Tourism Highlights and The Travel \& Tourism Competitiveness Report

Another indication of the territorial differentiation of UNESCO World Heritage Sites is the factor of economic development. Among the G20 countries only Argentina, Indonesia, Saudi Arabia, South Africa, South Korea are not included in the top twenty UNESCO World Heritage Sites, although the G20 countries account for more than half of these sites.

Almost half of the UNESCO heritage sites are in Europe (see Table 2), but there are some territorial differences: 19 countries have 10 or more sites. More than half of the European countries form the top twenty of the ranking. There are only two countries in Europe without World Heritage sites (Liechtenstein and the Kingdom of Monaco) (UNESCO World Heritage List).

The next region (according to the UNWTO classification), characterised by the specificity of linguistic and cultural environment, is the American macro-region, in which the leading positions in the number of UNESCO World Heritage sites is Mexico (35 sites) (see Table 1). In the structural distribution a significant advantage belongs to the cultural (30 sites) (UNESCO World Heritage List). The representative countries of the region are the United States (24 sites), Brazil (22), Canada (20), Peru (12), Argentina (11). The leader in visits is the United States (almost 77 million a year), and second and third places are Mexico and Canada (39 million and 20 million respectively) (UNWTO).

In the Asia-Pacific region there is a significant territorial differentiation in the distribution of UNESCO World Heritage Sites, which depends on the policy of governments to expand the base of sites with unique status. The leader of this region is China with 55 monuments. Every year 60 million tourists visit this country, and the presence of UNESCO sites is not the last reason to visit it. Significant potential for monuments has India (38 sites), which is the sixth in the ranking. However, it is the 20 th most visited country in the world (15.5 million tourists a year). This means that there is latent potential for tourism development. Japan (23 sites), Iran (24) and South Korea (14) also 
have considerable tourism potential with regard to available UNESCO heritage sites. We would like to single out Australia, where of the 20 World Heritage Sites, 16 are natural sites, which accounts for an even territorial division leading to a sustainable development of tourism. One of Australia's most famous World Heritage Sites is the Great Barrier Reef (UNESCO World Heritage List).

The least attractive region of the world is Africa, where there is not a single country that has more than 10 UNESCO World Heritage sites. On the negative side this region is represented by the Democratic Republic of Congo with 5 UNESCO monuments, but all of them are in danger of extinction or destruction. Rather significant potential of the UNESCO sites on the African continent is noted in South Africa (10 sites, 32nd place in the ranking), Ethiopia, Morocco ( 9 sites each), Tunisia ( 8 sites). This region has the most attractive potential among sites of natural value (UNESCO World Heritage List).

2. Evaluation of the impact of UNESCO World Heritage on international tourist arrivals. The main goal of tourism development in a particular territory is not the number of World Heritage sites, but the value of tourist flows and revenues from them. In our opinion, the assessment of the impact of the UNESCO World Heritage on the world tourism market can be compared with the indicator, which is calculated by UNWTO and demonstrates the international tourist arrivals. Of course, it is not necessary to identify all tourist arrivals with all UNESCO World Heritage sites as objects of tourist services. Of course, there may be another purpose for visiting a country. The task of our study was to identify the relationship between two socio-geographical phenomena: the number of UNESCO World Heritage sites and international tourist arrivals, which indirectly affect the world tourism market.

After performing a number of calculations, we obtained the results of the correlation analysis. We determined the correlation coefficient of the relationship between international tourist arrivals and the number of UNESCO sites. The world correlation coefficient is $(r=0.80378)$, which indicates a sufficiently close level of interrelation of the factors under study. The tendency of direct proportionality in this correlation relationship is clear. In other words, the more world heritage sites a country has, the greater the number of tourist arrivals, and vice versa. To better demonstrate to the world the correlation relationship between the number of UNESCO World Heritage sites and international tourist arrivals one can use a linear correlation graph (see Figure 1).

If we analyse the ranking data sets that were correlated, we see that there are 16 countries each in the top 20 of both rankings, which is $80 \%$ overlap (see Table 1). Sharp differences in the overall trends of correlated data with the advantage of World Heritage over international tourist arrivals have Iran (11th place in the ranking), Brazil (13th), Australia (15th), which have more than 20 sites each. However, their reasons are different: while Brazil and Australia have somewhat similar influences (remote geographical location relative to global tourist destinations), Iran, which has 24 UNESCO World Heritage Sites (11th place in the ranking), has less than 5 million tourists (42nd place in the visitor arrivals ranking). In our opinion, this is due to political reasons, security factor and religious freedoms. In other words, the country's tourism potential is not fully exploited, as demonstrated by the TTCI of 3.43, by which Iran ranks 50th in the ranking.

The opposite situation with the predominance of international arrivals over the World Heritage site base can be observed in the USA (10th place for World Heritage and 
Figure 1. Graph of the linear correlation distribution (World)

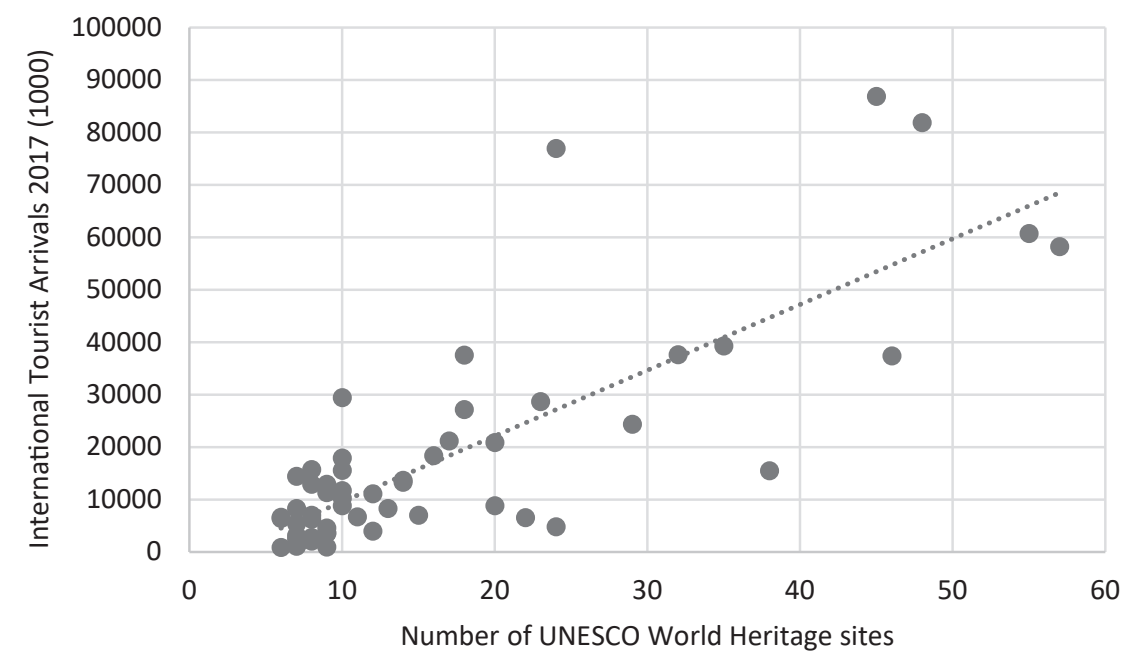

Source: calculated by the authors based on data from the UNESCO World Heritage List, UNWTO

3rd for international tourist arrivals), Turkey (respectively, 18th and 8th positions), Austria (27th, 10th), the Netherlands (31st, 17th). This means that the common root causes of visits to these countries are not World Heritage. These countries rank fairly high in the TTCI rankings, which confirms the above.

Let us single out the countries where there is a harmonious proportionality between the three indicators characterising the balance between the primary tourist motivation and destination possibilities. We included Spain (3rd place by the number of UNESCO monuments, 2nd place by international tourist arrivals, 1st place by TTCI), Great Britain and Northern Ireland (places in corresponding ratings -8 th, 7 th and 5 th), Portugal (18th, 14th and 12th), Czech Republic (21-22nd, 22nd and 25th), Bulgaria (27-32nd, 30th and 29-30th) and others. This situation is predominantly characteristic of European countries.

Therefore, we formed a separate sample of the data set within all the countries of the European continent and increased the statistical series in order to obtain a correct result for the analysis. The ranking includes 46 states. We deliberately combined Italy and the Vatican, and a correlation analysis was carried out using the same methodology, which demonstrated certain differences from global trends.

In Europe, the correlation coefficient between the number of UNESCO World Heritage sites and international tourist arrivals is $r=0.902664$, which is greater than the global value and demonstrates an even closer direct correlation between the said indicators. The linear regularity of the correlation distribution in the global trend is also confirmed on the European continent (see Figure 2).

Analysing the results, we note some interesting points: Ireland, having on its territory two UNESCO World Heritage sites (40th place), receives more than 10 million tourists annually, which in international tourist arrivals matches the level of Sweden, 


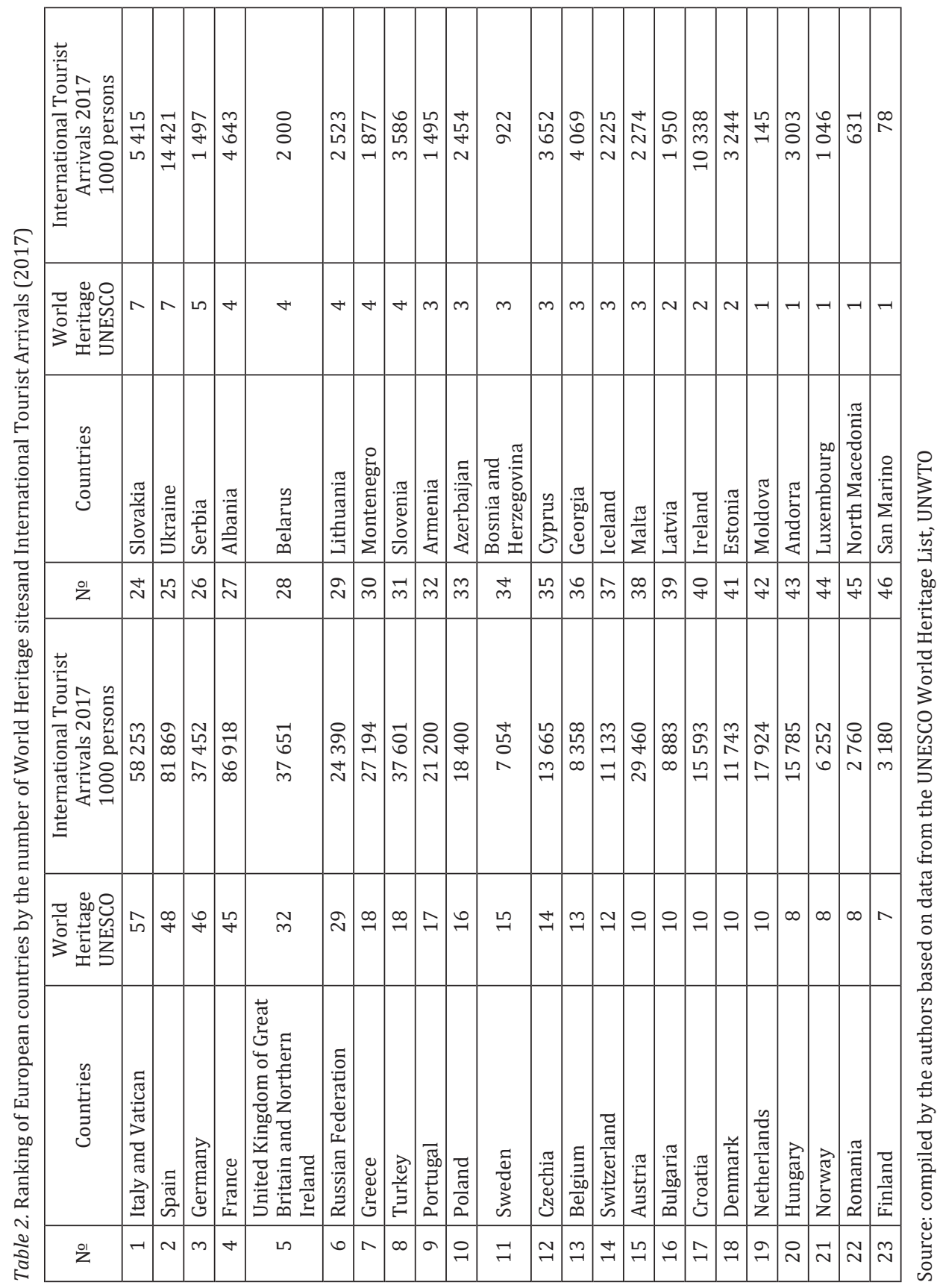


Figure 2. Linear correlation distribution graph (Europe)

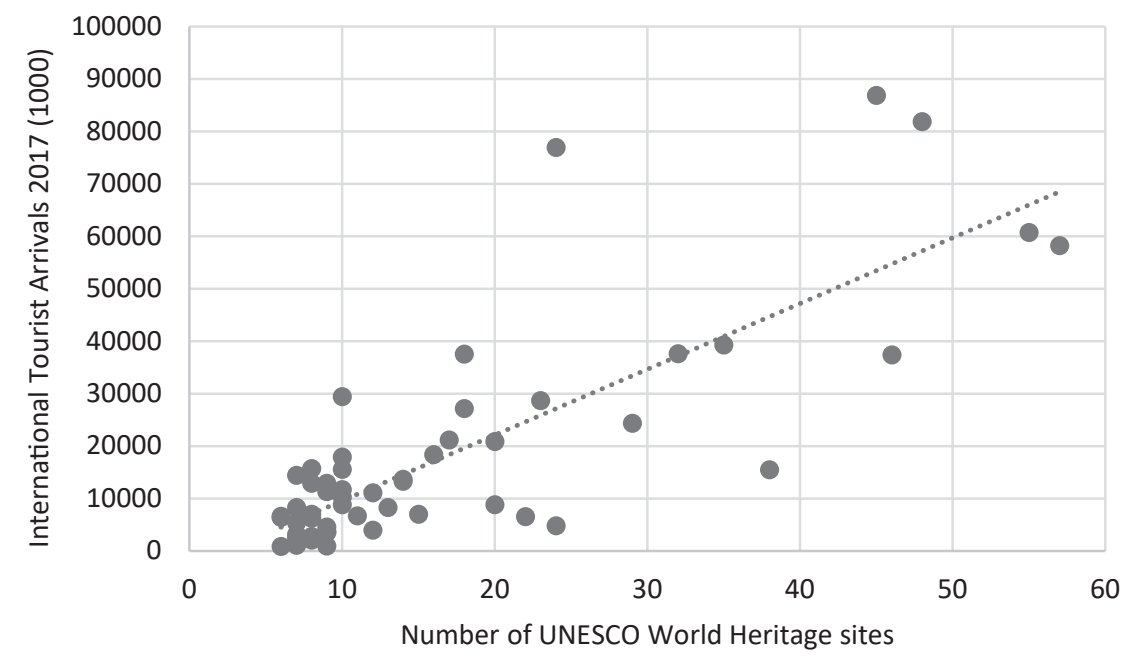

Source: calculated by the authors based on data from the UNESCO World Heritage List, UNWTO

Denmark, Bulgaria, Belgium, which have ten or more World Heritage sites in their arsenal. For example, Austria with its 10 UNESCO sites ( 9 of them are cultural), occupying 15th place in the ranking, is popular with almost 30 million tourists, and that is the 7th place by international tourist arrivals. It can be assumed that Austria's attractiveness is created by the Alpine ski resorts, which are the primary base attraction, and the cultural sites complement the tourist potential of the country.

3. The impact of World Heritage on a country's travel and tourism competitiveness index consists of four main groups of factors: environment, policy, infrastructure, natural and cultural resources. And those, in turn, cover another 14 indicators: legal regulation, ecology and environmental conditions, health and hygiene, priority of the tourist sector, air transport infrastructure, ground and port infrastructure, general tourist infrastructure, information and communication technologies, price competitiveness, human resources, level of hospitality, natural resources, cultural and historical resources. Their totality gives us an idea of the overall attractiveness of the destination.

Analysing TTCI as an indicator, we see that it demonstrates the civilizational level of tourist attractiveness and blurs the concept of the basic potential of tourist attractiveness, based, in our opinion, on the natural uniqueness and cultural richness. According to the TTCI indicators (see Table 3), the top ten countries have remained unchanged for the last two reports. Most of the countries in this ranking represent Europe, but Japan has made the most progress over the period.

However, we are more interested in the degree of correlation between World Heritage and TTCI. Having carried out the calculations using the same methodology of pairwise correlation, data for the world (see Table 1) data for Europe (see Table 2), we received the following data: the correlation coefficient between the number of World Heritage 
sites (World) and TTCI is 0.62776, a similar indicator was found in Europe (0.62344). In our opinion, this result indicates a non-obvious mutual influence of the two phenomena. In terms of the obtained mathematical value of the correlation coefficient, the closeness of the mutual influence, according to various estimates in the range from 0.5 to 0.65 , ranges from weak to medium. In fact, these are the indirect effects of the UNESCO World Heritage on the competitiveness of the tourism industry in the country.

Table 3. Ranking of countries by Travel and Tourism Competitiveness Index

\begin{tabular}{|c|c|c|c|c|}
\hline \multirow[b]{2}{*}{ Countries } & \multicolumn{2}{|c|}{2015} & \multicolumn{2}{|c|}{2017} \\
\hline & TTCI & $\begin{array}{l}\text { Place in the } \\
\text { ranking }\end{array}$ & TTCI & $\begin{array}{l}\text { Place in the } \\
\text { ranking }\end{array}$ \\
\hline Spain & 5.31 & 1 & 5.43 & 1 \\
\hline France & 5.24 & 2 & 5.32 & 2 \\
\hline Germany & 5.22 & 3 & 5.28 & 3 \\
\hline Japan & 4.94 & 9 & 5.26 & 4 \\
\hline $\begin{array}{l}\text { United Kingdom of Great Britain and } \\
\text { Northern Ireland }\end{array}$ & 5.12 & 5 & 5.20 & 5 \\
\hline USA & 5.12 & 4 & 5.12 & 6 \\
\hline Australia & 4.98 & 7 & 5.10 & 7 \\
\hline Italy & 4.98 & 8 & 4.99 & 8 \\
\hline Canada & 4.92 & 10 & 4.97 & 9 \\
\hline Switzerland & 4.99 & 9 & 4.94 & 10 \\
\hline
\end{tabular}

Source: compiled by the authors based on data from The Travel \& Tourism Competitiveness Report 20152017

The reason is that the UNESCO World Heritage is only one of many tools to increase the tourist attractiveness of the country. The overall competitiveness of the industry depends on investment, tourist safety and many other factors.

The most contrasting indicators are those of China, which shares with Italy the first place in the number of World Heritage sites, but ranks only 13 th in the attractiveness of tourism and travel. Equally striking are indicators for India (38 UNESCO sites, 6th place in the world), but in terms of TTCI only 26th. A similar picture is in the Russian Federation, which has 29 World Heritage Sites (9th place), and by TTCI 29 th. So, Spain is a successful country from the point of view of tourism development according to three indicators. It is the third in the number of World Heritage sites, the second in international tourist arrivals and the leader in the competitiveness of the tourism industry.

Separately, it is worth mentioning the high level of tourist arrivals and the competitiveness index of some countries, namely Singapore, Macao, Luxembourg, which are poor in terms World Heritage sites or even do not have them at all. These countries are an exception rather than a generalised trend. The basis of tourism development in these countries is not natural opportunities or cultural resources, but technological, infrastructural, entertainment and business opportunities. These are essentially onecity countries with no opportunities for spatial distribution of monuments, even if they would very much like it. Globally, the trend of the influence of World Heritage on tourist arrivals continues and correlation analysis confirms this, although fluctuating exceptions in the form of dwarf countries are present. 
Figure 3. Linear correlation distribution graphs (World)

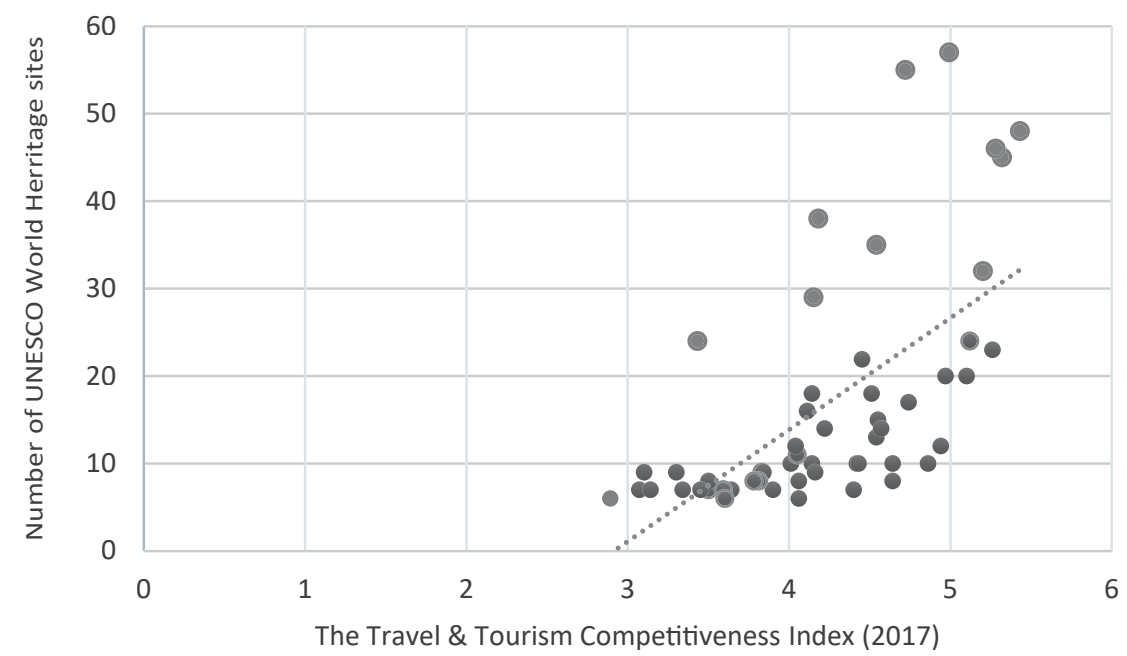

Source: calculated by the authors based on data from the UNESCO World Heritage List and The Travel \& Tourism Competitiveness Report 2017

Figure 4. Linear correlation distribution graphs (Europe)

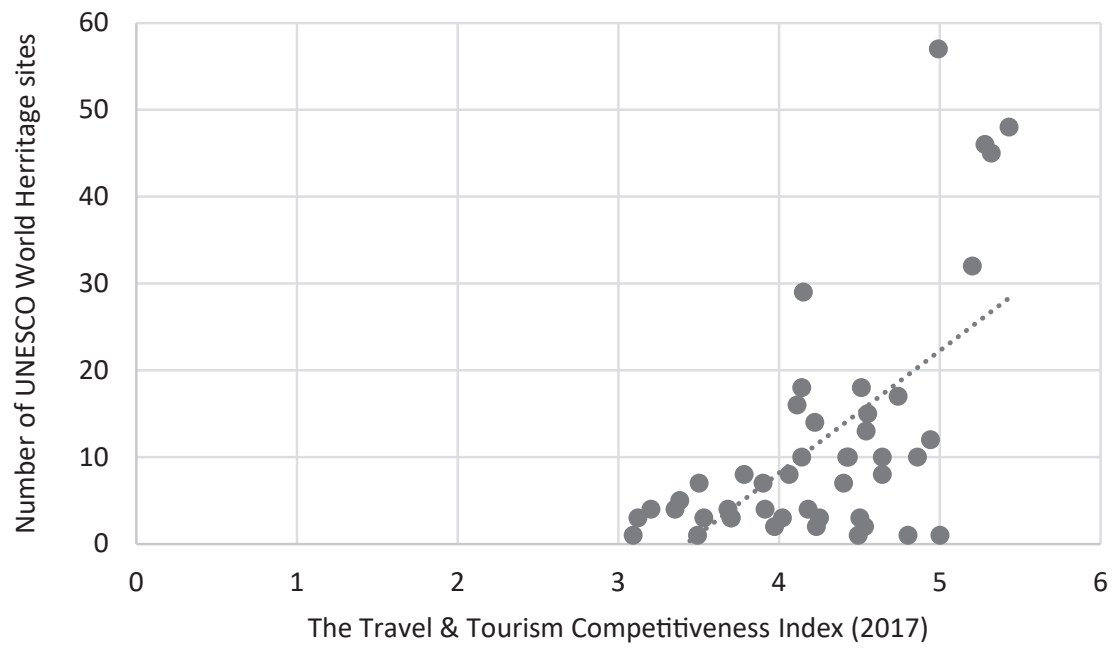

Source: calculated by the authors based on data from the UNESCO World Heritage List and The Travel \& Tourism Competitiveness Report 2017 


\section{CONCLUSIONS}

In our study, the evaluation of countries is considered as a quantitative attractiveness through the prism of tourist arrivals, which is due to the possibility of scientific measurement of this phenomenon. At the same time, we did not take into account the aesthetic attractiveness of the country (tourist sites) which is a subjective factor influenced by many conditions.

The territorial distribution of UNESCO World Heritage sites and destinations of tourist arrivals is usually not uniform on a planetary scale. However, the ranking distribution gave us the first idea of the place of the country in the general process of development of the attractiveness of the country and tourism in particular.

The study of the relationship between the number of UNESCO World Heritage sites and tourist arrivals confirms the simple truth that the state policy of increasing and preserving sites of World Heritage status will obviously contribute to the growth of tourist flows into the country, and therefore increase all indicators of the tourism industry, regardless of the purpose of travel. The current state of tourist flows, above all their volume, shows that the number of World Heritage sites in the country is an extremely attractive component of the choice of the purpose of tourist travel.

However, the influence of the UNESCO World Heritage on the development of the country's competitiveness is somewhat disproved, as evidenced by the insufficiently close correlation between these two phenomena. Competitiveness is influenced by other factors, levelling the possibilities of the natural and cultural basis.

It is important to note that the high level of correlation between the number of World Heritage sites and tourist arrivals should not be seen as the only way to increase the tourist flow into the country. Both today and in the future, it is only one of the tools to influence tourist attractiveness, but a very effective one.

In the near future, the tourism industry will face new challenges related to the post-pandemic period caused by the COVID-19 virus. Trends typical before 2020 may become irrelevant. In general, this epidemic has changed not only the world economy, social relations, but also the periodisation of the tourism industry. The tourism industry is entering a new era, which will be characterised by the creation of new man-made natural and cultural spaces, which will have all the elements of exoticism, uniqueness and inimitability. Newly created objects will compete with the UNESCO World Heritage for the future tourist, to shape his or her worldview. The first examples of such spaces can be seen in the UAE, Qatar, Singapore, and it can change the distribution of world tourist flows.

\section{References}

Baggio, R., Klobas, J.E. (2011). Quantitative Methods in Tourism. A Handbook. Bristol; Buffalo; Toronto: Channel View Publications.

Benckendorff, P. (2004). Planning for the Future. A Profile of Australian Tourist Attractions. $\mathrm{PhD}$ thesis for the degree of Doctor of Philogophy in the School of Business James Cook University. Retrived from https://researchonline.jcu.edu.au/970/2/02whole.pdf

Benckendorf, P. (2006). Attractions megatrends. In: D. Buhalis, C. Costa (eds.), Tourism business frontiers. Consumers, products and industry. Amsterdam; Boston: Elsevier ButterworthHeinemann, 200-210. doi: https://doi.org/10.1016/b978-0-7506-6377-9.50029-8 
Cmeciu, C.-M., Druga, L. (2011). Romanian Monasteries. Signs of tourist attraction and self-discovery. The European Legacy, 16(6), 751-768. doi: https://doi.org/10.1080/10848770.2011. 608008

Davidson, R. (1996). Turystyka. Warszawa: Polska Agencja Promocji Turystyki.

Du Cros, H. (2008). Too much of a good thing? Visitor congestion management issues for popular World Heritage tourist attractions. Journal of Heritage Tourism, 2(3). doi: https://doi. org/10.2167/jht062.0

Dwyer, L., Gill, A., Seetaram, N. (eds.). (2012). Handbook of Research Methods in Tourism. Quantitative and Qualitative Approaches. Edward Elgar Publishing. doi: https://doi. org/10.4337/9781781001295

Formica, S. (2004). Destination attractiveness as a function of supply and demand interaction. $\mathrm{PhD}$ Dissertation. Virginia Polytechnic Institute and State Univ. Retrived from https://www.semanticscholar.org/paper/Destination-Attractiveness-As-A-Function-Of-Supply-Formica/ 5721818e58e9d4d866426c0afe8a09fea4c8cecf

Formica, S., Uysal, M. (2006). Destination Attractiveness Based on Supply and Demand Evaluations. An Analytical Framework. Journal of Travel Research, 44(4), 418-430. doi: https://doi.org/10.1177/0047287506286714

Gao, Ya., Su, W., Zang, L. (2020). Does regional tourism benefit from the official rating of tourist attractions? Evidence from China's top-grade tourist attraction accreditations. Journal of China Tourism Research. doi: https://doi.org/10.1080/19388160.2020.1822975

Glăvan, V. (2005). Geography of Tourism. Bucharest: Fundației România de Mâine. Retrieved from https://www.scribd.com/doc/83550129/Geografia-Turismului-Vasile-Glavan

Goeldner, C.R., Ritchie, J.R.B. (2003, 2009). Tourism. Principles, Practices, Philosophies. Hoboken, NJ: John Wiley \& Sons. Retrieved from https://www.entornoturistico.com/wp-content/ uploads/2018/04/Tourism-Principles-Practices-Philosophies.pdf

Hair, J.F., Black, W.C., Babin, H.J., Anderson, R.E. (2010). Multivariate data analysis. (7th ed.). New Jersey: Prentice Hall. Retrieved from https://www.academia.edu/6955544/Joseph_F_ Hair_William_C_Black_Barry_J_Babin_Rolph_E_Anderson_Multivariate_Data_Analysis_7th_Edition_2009

Hall, C.M., Page, S.J. (2014). The Geography of Tourism and Recreation. Environment, Place and Space. (4th ed.). London: Routledge. doi: https://doi.org/10.4324/9780203796092.

Husbands, W.C. (1983). Tourist space and tourist attraction. An analysis of destination choices of European travelers. Leisure Sciences, 5(4), 289-307. doi: https://doi. org/10.1080/01490408309513010

Iațu, C., Bulai, M. (2011). New approach in evaluating tourism attractiveness in the region of Moldavia (Romania). International Journal of Energy and Environment, 5(2), 165-174. Retrieved from https://www.researchgate.net/publication/283360314_New_approach_ in_evaluating_tourism_attractiveness_in_the_region_of_Moldavia_Romania

Ielenicz, M., Comănescu, L. (2006). România-potenţial turistic. Bucureşti: Edit. Universitară.

Ielenicz, M., Comănescu, L., Nedelea, A. (2010). Romania's touristic potential. The differentiation of the potential units. South Asian Journal of Tourism and Heritaje, 3(1), 26-38. Retrieved from https://www.sajth.com/old/2010/Microsoft\%20Word\%20-\%2003.pdf

Ivanunik, V., Yavkin V. (2012). Attractiveness of recreational and tourist areas. Textbook. Chernivtsi: Chernivtsi National University [in Ukrainian]. Retrieved from https://tourlib. net/books_ukr/ivanunik.htm

Kaharuddin, K., Napitupulu, J., Juliana, J., Pramono, R., Saragih., E. (2021). Determinants of Tourist Attraction of the Heritage Tourism. Journal of Environmental Management and Tourism, 12(2), 507-514. doi: https://doi.org/10.14505//jemt.12.2(50).19

Kempiak, J., Hollywood, L., Bolan, P., McMahon-Beattie, U. (2017). The heritage tourist. An understanding of the visitor experience at heritage attractions. International Journal of Heritage Studies, 23(4), 375-392. doi: https://doi.org/10.1080/13527258.2016.1277776

Korol, O., Krul, V. (2020). Classification of Countries of Destination by Gross and Relative Values of International (inbound) Tourism and its Factors. Prace Komisji Geografii Przemyslu Polskiego Towarzystwa Geograficznego [Studies of the Industrial Geography Commission of the Polish Geographical Society], 34(3), 130-149. doi: https://doi.org/10.24917/20801653.343.9 
Kruczek, Z. (2011). Atrakcje turystyczne. Fenomen, typologia, metody badań. Kraków Proksenia. Retrieved from https://docplayer.pl/551208-Zygmunt-kruczek-atrakcje-turystyczne-fenomen-typologia-metody-badan.html

Kruczek, Z. (2015). Analysis of Visitor Attendance at Polish Tourism Attractions. Tourism, 25(1), 47-56. doi: https://doi.org/10.2478/tour-2014-0019

LEADER II European Observatory. (2011). Evaluating a territory's tourism potential. Retrieved from http://www.cosimonotarstefano.it/files/1_EvaluatingTerritory.pdf

Leiper, N. (1979). The framework of tourism. Towards a definition of tourism, tourist, and the tourist industry.Annals of Tourism Reseach, 6(4), 390-407. doi: https://doi.org/10.1016/01607383(79)90003-3

Lew, A. (1987). A framework of tourist attraction research. Annals of Tourism Research, 14(4), 553-575. doi: https://doi.org/10.1016/0160-7383(87)90071-5

Lovingwood, P., Mitchell, L. (1989). Regional analysis of South Carolina tourism. Annals of Tourism Research, 16(3), 301-317. doi: https://doi.org/10.1016/0160-7383(89)90046-7

Lundberg, D. (1985). The Tourist Business. New York: Van Nostrand Reinhold.

McKenzie, G., Adams, B. (2018). A data-driven approach to exploring similarities of tourist attractions through online reviews. Journal of Location Based Services, 12(2). doi: https://doi.org/ $10.1080 / 17489725.2018 .1493548$

Middleton, V. (1996). Marketing w turystyce. Warszawa: Polska Agencja Promocji Turystyki.

Middleton, V. (2003). A national strategy for visitor attractions. In: A. Fyall, B. Garrod, A. Leask (eds.), Managing Visitor Attractions. New Directions. Oxford: Butterworth-Heinemann, 270283. doi: https://doi.org/10.4324/9780080496368

Muntele, I., Iațu, C. (2006). Tourism geography. Concepts, methods, spatial patterns. Iați: Sedcom Libris.

Scott, N., Baggio, R., Cooper, C. (2008). Network Analysis and Tourism. From Theory to Practice. Bristol; Blue Ridge Summit: Channel View Publications. doi: https://doi. org/10.21832/9781845410896.

Smith, S.L.J. (1987). Regional Analysis of Tourism Resources. Annals of Tourism Research, 14(2), 254-273. doi: https://doi.org/10.1016/0160-7383(87)90088-0

The Travel \& Tourism Competitiveness Report 2015. Retrieved from http://www3.weforum.org/ docs/TT15/WEF_Global_Travel\&Tourism_Report_2015.pdf

The Travel \& Tourism Competitiveness Report 2017. Retrieved from https://www.weforum.org/ reports/the-travel-tourism-competitiveness-report-2017

Truchet, S., Piguet, V., Aubert, F., Callois, J.-M. (2016). Spatial influence of attractions on tourism development. Tourism Geographies, 18(5). doi: https://doi.org/10.1080/14616688.2016.1 221985

UNESCO World Heritage List. (Report for 2017). Retrieved from https://whc.unesco.org/en/list

UNWTO Tourism Highlights. (2017). Retrieved from https://www.e-unwto.org/doi/ pdf/10.18111/9789284419029

Vitalii Ivanunik, PhD, Yuriy Fedkovych Chernivtsi National University (Chernivtsi, Ukraine), Department of Geography and Management of Tourism. PhD in Geography, associate professor. He has graduated from the Yuriy Fedkovych Chernivtsi National University. Author's research interests concern issues of international tourism flows, tourist attraction of the territory, guided tour service, world heritage sites.

\title{
ORCID: https://orcid.org/0000-0003-3879-1998
}

\section{Address:}

\author{
Yuriy Fedkovych Chernivtsi National University \\ 2 Kotsyubynskyi Str. \\ 58012 Chernivtsi, Ukraine \\ e-mail:v.ivanunik@chnu.edu.ua
}

Halyna Krul, PhD in Geography, associate professor of the Department of Geography and Management of Tourism, Yuriy Fedkovych Chernivtsi National University (Chernivtsi, Ukraine). Graduated from the Yuriy Fedkovych Chernivtsi National University. The author's research interests relate to the hotel and restaurant business, recreational geography, tourism resources, hospitality and service. 
ORCID: https://orcid.org/0000-0001-9760-5468

\section{Address:}

Yuriy Fedkovych Chernivtsi National University

2 Kotsyubynskyi Str.

58012 Chernivtsi, Ukraine

e-mail: g.krul@chnu.edu.ua

Stepan Bryk, PhD in Geography, assistant professor in the Department of Geography and Management of Tourism, Deputy Dean of the Faculty of Geography for educational work, Yuriy Fedkovych Chernivtsi National University (Chernivtsi, Ukraine). Graduated from the Yuriy Fedkovych Chernivtsi National University. Author's research interests concern issues of international tourism flows, international tourism market, tourism marketing, tourism animation, guided tour service.

ORCID: https://orcid.org/0000-0002-2992-1634

\section{Address:}

Yuriy Fedkovych Chernivtsi National University

2 Kotsyubynskyi Str.

58012 Chernivtsi, Ukraine

e-mail: s.bryk@chnu.edu.ua 